\title{
Pengaruh Pergantian Manajemen dan Audit Fee pada Auditor Switching Dengan Reputasi Auditor Sebagai Variabel Pemoderasi
}

\author{
Made Widi Wulandari ${ }^{1}$ \\ I Dewa Gede Dharma Suputra ${ }^{2}$ \\ ${ }^{1}$ Fakultas Ekonomi dan Bisnis Universitas Udayana (Unud), Bali, Indonesia \\ email: widiwulandari13@yahoo.com/ Telp: 087862340537 \\ ${ }^{2}$ Fakultas Ekonomi dan Bisnis Universitas Udayana (Unud), Bali, Indonesia
}

\begin{abstract}
ABSTRAK
Pergantian auditor merupakan perilaku yang dilakukan perusahaan klien untuk melakukan perpindahan auditor. Tujuan dari penelitian ini adalah untuk mengetahui dan membuktikan secara empiris pengaruh pergantian manajemen dan audit fee pada auditor switching dengan reputasi auditor sebagai variabel pemoderasi. Penelitian ini dilakukan pada perusahaan sektor manufaktur yang terdaftar di Bursa Efek Indonesia (BEI) tahun 2012-2016. Populasi dalam penelitian ini berjumlah 144 perusahaan, dengan menggunakan teknik purposive sampling diperoleh sampel penelitian sejumlah 18 perusahaan. Teknik analisis data yang digunakan adalah analisis statistik deskriptif, analisis regresi logistik dan uji interaksi. Hasil pengujian menunjukkan bahwa pergantian manajemen memiliki pengaruh positif pada auditor switching, kemudian audit fee tidak berpengaruh pada auditor switching dan reputasi auditor tidak dapat memoderasi pengaruh pergantian manajemen dan audit fee pada auditor switching.
\end{abstract}

Kata Kunci: auditor switching, pergantian manajemen, audit fee.

\begin{abstract}
Auditor turnover is a behavior that the client company does to transfer the auditor. The purpose of this research is to know and prove empirically the effect of management change and audit fee on switching auditor with auditor reputation as moderator variable. This research was conducted at manufacturing sector companies listed in Indonesia Stock Exchange (BEI) year 2012-2016. The population in this study amounted to 144 companies, by using purposive sampling technique obtained by a sample of 18 companies. Data analysis techniques used are descriptive statistical analysis, logistic regression analysis and interaction test. The test results show that the change of management has a positive influence on the switching auditor, then audit fee has no effect on the switching auditor and the auditor's reputation can not moderate the effect of switching management on the switching auditor.
\end{abstract}

Keywords: auditors switching, change of management, audit fees.

\section{PENDAHULUAN}

Secara umum auditing adalah suatu proses sistematik untuk memperoleh dan mengevaluasi bukti secara objektif mengenai pernyataan-pernyataan tentang kebijakan ekonomi, dengan tujuan untuk menetapkan tingkat kesesuaian antara pernyataan-pernyataan tersebut dengan kriteria yang telah ditentukan, serta 
Made Widi Wulandari dan I Dewa Gede Dharma Suputra. Pengaruh...

menyampaikan hasilnya kepada pihak yang berkepentingan. Timbul dan berkembangnya suatu profesi akuntan publik dipengaruhi oleh perkembangan perusahaan publik pada umumnya, artinya semakin banyak perusahaan yang berdiri semakin banyak pula jasa akuntan publik yang dibutuhkan. Oleh karena itu, Kantor Akuntan Publik saling bersaing untuk mendapatkan klien dengan berusaha memberikan jasa audit sebaik mungkin dengan menyajikan laporan keuangan secara wajar (Utami, 2013).

Laporan keuangan digunakan sebagai dasar dalam menentukan atau menilai posisi dan kegiatan operasional perusahaan. Peran akuntan publik diperlukan untuk memastikan bahwa laporan keuangan yang disajikan perusahaan dapat dipercaya dan menyajikan informasi yang sebenarnya dan sewajarnya (Juliantari \& Rasmini, 2013). Fenomena pergantian auditor atau pergantian Kantor Akuntan Publik sering terjadi di Indonesia, salah satu penyebab adanya regulasi pemerintah dan independensi. Isu independensi sering digunakan sebagai alasan untuk melakukan penggantian auditor, salah satu skandal pada perusahaan Enron dengan KAP Arthur Anderson di Amerika Serikat pada tahun 2001 merupakan fakta yang terjadi akibat hubungan auditor dan klien yang terjalin lama. Kasus Enron mengakibatkan terpuruknya KAP Arthur Anderson, dimana KAP tersebut merupakan lima KAP besar di dunia atau Big Five.

Terjalinnya hubungan yang erat antara auditor dengan kliennya membuat KAP Arthur Anderson terlibat dalam kecurangan di perusahaan Enron yang pada akhirnya membuat KAP tersebut runtuh dan kehilangan independensinya. Salah satu hal yang dipertimbangkan dalam pengambilan keputusan untuk melakukan 
pergantian KAP adalah pergantian manajemen. Pergantian manajemen yang dimaksud dalam hal ini adalah pergantian direksi utama, disebabkan karena keputusan rapat umum pemegang saham atau pihak manajemen berhenti karena kemauannya sendiri (Pradhana, 2015). Manajemen yang baru cenderung akan lebih memilih KAP yang berafiliasi dengan Big Four. Jika manajemen sebelumnya telah menggunakan KAP Big Four, maka manajemen baru tidak akan menurunkan kualitas dari KAP yang digunakan.

Terdapat beberapa penelitian yang mendukung bahwa pergantian manajemen memengaruhi adanya pergantian auditor atau auditor switching diantaranya penelitian yang dilakukan oleh (Cooke, 2005), (Astika \& Pratini, 2013) serta (Saputra, 2015). Pada penelitian lain terdapat hasil-hasil yang berbeda. Hal ini ditunjukkan oleh penelitian dari (Wahyuningsih \& K, 2012), (Wayan et al., 2013), (Satriantini et al., 2014), menemukan bahwa pergantian manajemen tidak berpengaruh pada pergantian auditor.

Pergantian KAP yang sering cenderung akan mengakibatkan peningkatan audit fee. Besarnya fee auditor dapat bervariasi tergantung pada risiko penugasan, kompleksitas jasa yang diberikan, tingkat keahlian yang diperlukan melakukan jasa tersebut dan pertimbangan profesional lainnya (Ramantha, 2014). Hasil penelitian (Sari, 2016) menyatakan bahwa audit fee berpengaruh positif pada auditor switching. Hal ini menunjukkan bahwa semakin tinggi audit fee yang ditawarkan auditor maka perusahaan akan semakin sering melakukan auditor switching. Hasil penelitian ini selaras dengan (Calderon \& Ofobike, 2007), (Ramantha, 2014), serta (Pradhana, 2015). Namun bertolak belakang dengan 
Made Widi Wulandari dan I Dewa Gede Dharma Suputra. Pengaruh...

penelitian (Chadegani et al., 2011), (Lestari, 2012), dan (Arinta \& Adiwibowo, 2013), serta (Suyono et al., 2013) yang menyatakan bahwa tidak terdapat pengaruh audit fee pada auditor switching.

Berdasarkan pada penelitian terdahulu, terdapat ketidakkonsistenan hasil yang terjadi pada faktor-faktor yang dapat menyebabkan perusahaan melakukan auditor switching. Hal ini memotivasi peneliti untuk melakukan penelitian dengan menggunakan variabel moderasi reputasi auditor dalam memperkuat atau memperlemah pengaruh pergantian manajemen dan audit fee pada auditor switching. Reputasi auditor digunakan sebagai variabel pemoderasi dalam penelitian ini, karena auditor yang bereputasi baik memiliki keahlian audit yang lebih tinggi dan akan menghasilkan kualitas audit yang lebih baik pula dengan begitu perusahaan dapat menarik calon investor sehingga kepercayaan masyarakat terhadap perusahaan akan meningkat (Nasser et al., 2006).

Penelitian yang dilakukan (Sidhi \& Wirakusuma, 2015) menunjukkan bahwa reputasi KAP berpengaruh terhadap auditor switching. Hal tersebut membuat audit fee KAP Big 4 lebih tinggi dibandingkan non Big 4. Pembayaran audit fee yang tinggi pada kondisi tertentu akan semakin membebani perusahaan, sehingga dalam kondisi tersebut dapat mendorong perusahaan untuk melakukan auditor switching. Namun bertolak belakang dengan penelitian yang dilakukan (Suyono et al., 2013) menunjukkan bahwa reputasi auditor tidak berpengaruh terhadap auditor switching.

Rumusan masalah yang dapat diajukan yaitu Apakah pergantian manajemen berpengaruh pada auditor switching?, Apakah audit fee berpengaruh 
pada auditor switching?, Apakah reputasi auditor dapat memoderasi pengaruh pergantian manajemen pada auditor switching?, serta Apakah reputasi auditor dapat memoderasi pengaruh audit fee pada auditor switching?.

Tujuan penelitian ini diharapkan dapat memberikan pemahaman dan wawasan yang luas mengenai pengaruh pergantian manajemen dan audit fee pada auditor switching dengan reputasi auditor sebagai variabel pemoderasi. Hasil penelitian ini juga diharapkan dapat memberikan dukungan kepada teori yang digunakan, yaitu teori keagenanan dan kontingensi. Selain itu, hasil penelitian ini diharapkan dapat dijadikan sebagai sumber refrensi dan informasi untuk penelitian selanjutnya dalam pengembangan pengauditan khususnya auditor switching.

Teori keagenan mengungkapkan adanya perbedaan kepentingan antara pemegang saham sebagai principal dan manajemen sebagai agennya. Perbedaan kepentingan ini muncul akibat terpisahnya fungsi antara kepemilikan dan agen yang disebut sebagai masalah keagenan (agency problem). Timbulnya konflik ini dikarenakan pihak manajemen yang berperan sebagai agen memiliki dan mengejar kepentingan pribadinya dalam menjalankan perusahaan. Hal ini akan membuat kepentingan maupun keinginan dari pemegang saham sebagai pemilik perusahaan tidak dapat dicapai.

Manajemen sebagai pengelola perusahaan umumnya memiliki informasi yang lebih banyak dibandingkan dengan principal, karena pihak manajemen merupakan agen yang menjalankan perusahaan secara langsung sehingga segala bentuk informasi yang terkait dengan perusahaan akan diketahui pertama kali oleh manajemen. Begitu pula dengan kondisi perusahaan yang sebenarnya manajemen 
Made Widi Wulandari dan I Dewa Gede Dharma Suputra. Pengaruh...

dapat memaparkan kondisi perusahaan yang berbeda dengan kondisi perusahaan yang sebenarnya. Hal ini tentu saja menimbulkan adanya asimetri informasi (information asymmetry). Teori kontingensi diperkenalkan pertama kali oleh (Lawrence \& Lorsch, 1967) yang kemudian digunakan kembali oleh (Kast \& Rosenzweig, 1973) yang mengungkapkan bahwa, sebuah organisasi tidak memiliki cara terbaik dalam memperoleh keserasian antara faktor internal organisasi maupun faktor lingkungan eksternalnya untuk dapat menggapai prestasi terbaik. Teori ini tentu saja penting sebagai sarana untuk menjelaskan perbedaan dalam struktur organisasi.

Auditor Switching merupakan pemutusan perikatan dan pergantian perikatan jasa audit umum dengan Kantor Akuntan Publik maupun Akuntan Publik yang dilakukan oleh perusahaan sebagai klien (Susanto, 2015). Terdapat dua faktor yang menyebabkan auditor switch yaitu faktor terkait auditor (auditor related factor), yaitu: fee audit, opini audit, dan kualitas audit dan faktor yang berasal dari klien (client related factor) yaitu: ukuran perusahaan, pergantian manajemen dan kesulitan keuangan (Ali, 2015). Pergantian manajemen dilakukan dengan melihat kondisi perusahaan dimana struktur manajemen yang ada ternyata tidak mampu mengelola perusahaan dengan baik (Pradhana, 2015).

Pergantian manajemen sebagai pergantian direksi perusahaan yang disebabkan karena keputusan pada saat Rapat Umum Pemegang Saham (RUPS) maupun direksi mengundurkan diri dari pekerjaannya atas keinginan sendiri. Adanya pergantian manajemen yang baru, akan menimbulkan adanya perubahan kebijakan dalam bidang akuntansi, keuangan, dan juga pemilihan KAP 
(Damayanti \& Sudarma, 2008). Perusahaan akan berusaha mencari auditor yang mampu sejalan dan sepakat dengan kebijakan akuntansi yang berlaku di perusahaan tersebut (Nagy, 2005). Audit fee merupakan hak yang didapat oleh auditor atas jasa yang telah diberikan kepada klien dan penentuan audit fee harus disepakati bersama baik oleh klien maupun auditor tersebut, agar tidak terjadi perang tarif yang dapat merusak kredibilitas akuntan publik. Reputasi auditor merupakan nama besar yang dimiliki auditor atas prestasi dan kepercayaan publik yang disandang auditor tersebut. Reputasi auditor merupakan salah satu proksi kualitas audit (Widyanti, A.A. S Istri \& Badera, 2016).

Adapun kerangka konseptual dalam penelitian ini menunjukkan pengaruh antar variabel dalam penelitian. Kerangka konseptual dalam penelitian ini disajikan pada gambar 1 sebagai berikut.

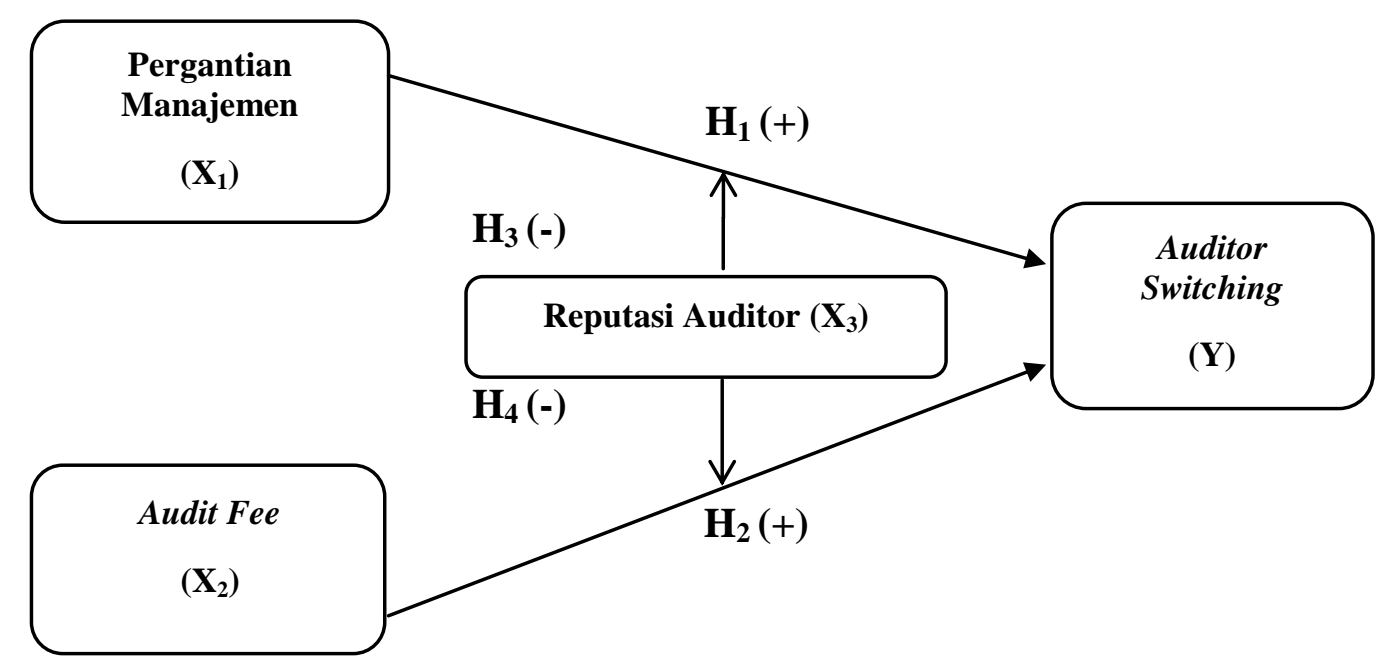

\section{Gambar 1. Kerangka Konseptual}

Pada teori keagenan, adanya perbedaan tujuan dan kepentingan antara principal dan agen memicu timbulnya agency problem. Manajemen yang berperan sebagai agen memiliki dan mengejar kepentingan pribadinya dalam menjalankan perusahaan sehingga kepentingan atau keinginan dari pemegang 
Made Widi Wulandari dan I Dewa Gede Dharma Suputra. Pengaruh...

saham sebagai pemilik perusahaan tidak dapat dicapai. Hal ini membuat principal kehilangan kepercayaan kepada agen dan memilih mengganti manajemen perusahaan. Penelitian yang dilakukan menyatakan bahwa pergantian manajemen berpengaruh positif pada auditor switching. Hal ini didukung oleh hasil penelitian yang telah dilakukan oleh (Astika \& Pratini, 2013) dan (Pawitri \& Yadnyana, 2015). Pergantian manajemen tidak selalu diiringi dengan pergantian kebijakan perusahaan dalam menggunakan jasa akuntan publik atau Kantor Akuntan Publik. Hal tersebut menunjukkan bahwa saat perusahaan berganti direktur utama mampu menyelaraskan kebijakan-kebijakan yang telah ada sebelumnya dengan kebijkankebijakan yang baru dia buat termasuk dalam pemilihan akuntan publik atau Kantor Akuntan Publik. Sehingga apabila terdapat pergantian direktur utama dengan kebijakan-kebijkan yang baru, hal ini tidak menjamin bahwa perusahaan perusahaan akan melakukan auditor switching. Berdasarkan kajian teori dan dan empiris maka dapat dirumuskan hipotesis adalah sebagai berikut.

$\mathrm{H}_{1}$ : Pergantian manajemen berpengaruh positif pada auditor switching.

Monitoring cost yaitu dalam bentuk audit fee, merupakan biaya yang dikeluarkan perusahaan untuk pengawasan yang dilakukan oleh pihak independen. Menurut penelitian yang dilakukan (Siregar et al., 2012) menyatakan bahwa semakin tinggi audit fee yang ditawarkan dan perusahaan merasa tidak puas dengan kantor akuntan publik (KAP) tersebut maka perusahaan akan melakukan pergantian KAP. Hasil penelitian (Sari, 2016) juga menyatakan bahwa audit fee berpengaruh positif pada auditor switching. Hal ini menunjukkan bahwa semakin tinggi audit fee yang ditawarkan auditor maka perusahaan akan semakin 
sering melakukan auditor switching. Berdasarkan kajian teori dan empiris maka dapat dirumuskan hipotesis adalah sebagai berikut.

$\mathrm{H}_{2}$ : Audit fee berpengaruh positif pada auditor switching.

Pergantian manajemen menimbulkan terjadinya perubahan dalam kebijakan perusahaan termasuk kebijakan menggunakan jasa kantor akuntan publik (Astika \& Pratini, 2013). Berdasarkan teori kontingensi, perbedaan desakan lingkungan perusahaan menjadi acuan pihak manajemen dalam memilih sistem akuntansi yang akan diberlakukan di perusahaan tersebut. Pihak manajemen yang baru cenderung akan lebih memilih untuk mencari auditor yang setuju dengan seluruh kebijakan baru yang diterapkan perusahaan (Wijayana \& Januarti, 2011). Perusahaan dalam memilih jasa KAP yang akan digunakan tentunya memiliki kriteria tertentu, salah satunya memilih KAP yang bereputasi. Perusahaan yang diaudit oleh KAP skala besar (Big 4) cenderung akan tetap mempertahankan auditornya untuk menjaga kualitas audit karena KAP yang lebih besar dianggap mampu menghasilkan kualitas audit yang baik dan dapat mempertahankan reputasi yang tinggi dalam lingkungan bisnis (Astrini \& Muid, 2013). Berdasarkan kajian teori dan empiris maka dapat dirumuskan hipotesis adalah sebagai berikut.

$\mathrm{H}_{3}$ : Reputasi auditor memperlemah pengaruh pergantian manajemen pada auditor switching.

Menurut penelitian yang dilakukan (Francis \& Yu, 2009) menjelaskan bahwa KAP skala besar (Big 4) menghasilkan kualitas audit yang lebih baik dan cenderung lebih cepat menyelesaikan laporan auditornya dibandingkan dengan KAP skala kecil atau non Big 4. Menurut (El-Gammal, 2012) menyatakan bahwa 
Made Widi Wulandari dan I Dewa Gede Dharma Suputra. Pengaruh...

perusahaan-perusahaan di Lebanon lebih mencari KAP yang bereputasi baik meskipun harus membayar audit fee yang lebih tinggi, agar menghasilkan laporan audit yang berkualitas bagi perusahaan. Apabila perusahaan telah menggunakan jasa KAP yang bereputasi dan hal tersebut dapat meningkatkan nama baik perusahaan khususnya dimata investor, maka perusahaan tidak akan melakukan pergantian KAP untuk mengaudit laporan keuangan walaupun fee yang ditawarkan KAP tersebut cukup tinggi (Sari, 2016). Semakin sering jasa Kantor Akuntan Publik (KAP) dipercaya untuk mengaudit laporan keuangan perusahaan maka semakin tinggi reputasi KAP tersebut. Berdasarkan kajian teori dan empiris maka dapat dirumuskan hipotesis adalah sebagai berikut.

$\mathrm{H}_{4}$ : Reputasi auditor memperlemah pengaruh audit fee pada auditor switching.

\section{METODE PENELITIAN}

Penelitian ini merupakan penelitian asosiatif kuantitatif. Lokasi penelitian ini dilakukan pada perusahaan manufaktur yang terdaftar di Bursa Efek Indonesia. Obyek penelitian yang dipilih peneliti adalah auditor switching yang diukur dengan pergantian manajemen, audit fee, dan reputasi auditor. Reputasi auditor dalam penelitian ini berfungsi sebagai pemoderasi pengaruh antara variabel dependen dengan independen.

Pergantian manajemen diartikan sebagai pergantian direksi utama perusahaan yang disebabkan oleh keputusan RUPS (Rapat Umum Pemegang Saham) dan berhenti karena kemauannya sendiri. Adanya pergantian manajemen memungkinkan timbulnya peraturan dan kebijakan baru yang diterapkan perusahaan. Pergantian manajemen diukur dengan menggunakan dummy. Kode 1 
diberikan apabila terjadi pergantian direktur utama pada perusahaan, kode 0 diberikan apabila tidak terjadi pergantian direktur utama pada perusahaan (Pawitri \& Yadnyana, 2015).

Auditfee adalah salah satu hak yang didapatkan oleh auditor atas jasa yang telah diberikan kepada klien. Audit fee dalam penelitian ini diukur dengan menggunakan proksi logaritma natural pada profesional fee atau honorarium tenaga ahli yang dibayar oleh klien (Wijaya, 2015).

Populasi dalam penelitian ini adalah seluruh perusahaan manufaktur yang terdaftar di Bursa Efek Indonesia periode tahun 2012-2016. Sampel dalam penelitian ini adalah perusahaan manufaktur yang telah dipilih menggunakan metode purposive sampling di Bursa Efek Indonesia (BEI) tahun 2012-2016. Metode penentuan sampel yang digunakan peneliti dalam penelitian ini adalah metode non-probability sampling, yaitu cara pengambilan sampel dimana tiap anggota sampel tidak memiliki kesempatan yang sama untuk dipilih sebagai sampel. Teknik yang digunakan dalam metode ini adalah teknik purposive sampling.

Berdasarkan metode tersebut jumlah observasi yang diperoleh untuk penelitian adalah sebanyak 18 perusahaan dengan 90 total amatan. Pada penelitian ini mempergunakan metode pengumpulan data observasi nonpartisipan. Dilakukan Uji Statistik Deskriptif, Uji Kelayakan Model Regresi hingga Uji Regresi Logistik yang menghasilkan persamaan sebagai berikut.

$\boldsymbol{L n} \frac{\boldsymbol{p}(\boldsymbol{Y})}{\boldsymbol{1 - P}(\boldsymbol{Y})}=\alpha_{1}+\beta_{1} X_{1}+\beta_{2} X_{2}+\beta_{3} X_{3}+\beta_{4} X_{1} . X_{3}+\beta_{5} X_{2} . X_{3}+\varepsilon$

Keterangan: 


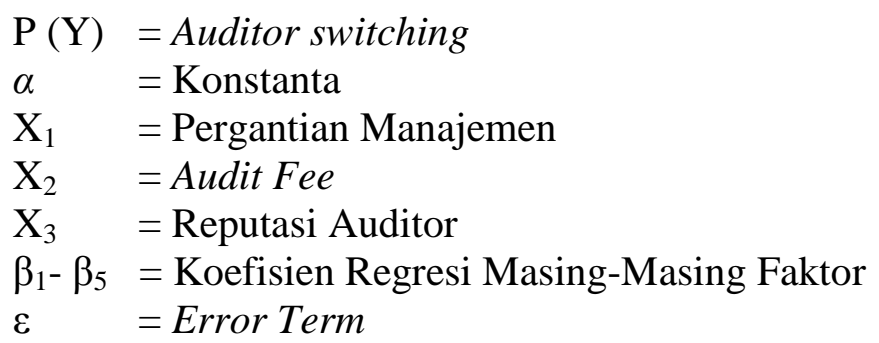

\section{HASIL DAN PEMBAHASAN}

Setelah dilakukan observasi penelitian, perusahaan yang dapat dijadikan sampel sebanyak 18 perusahaan dengan total 90 sampel amatan yang ditunjukan dengan proses seleksi sebagai berikut.

Tabel 1.

Hasil Seleksi Pemilihan Sampel

\begin{tabular}{rlc}
\hline No & \multicolumn{1}{c}{ Kriteria } & Jumlah \\
& & Perusahaan \\
\hline & $\begin{array}{l}\text { Populasi } \\
1\end{array}$ & $\begin{array}{l}\text { Perusahaan manufaktur yang tidak terdaftar berturut-turut di } \\
\text { BEI pada tahun 2012-2016 }\end{array}$ \\
2 & $\begin{array}{l}\text { Perusahaan tidak menerbitkan laporan keuangan tahunan yang } \\
\text { Berakhir 31 desember serta diaudit oleh auditor independen }\end{array}$ \\
3 & $\begin{array}{l}\text { Perusahaan tidak melakukan pergantian KAP selama tahun } \\
\text { Amatan }\end{array}$ \\
4 & $\begin{array}{l}\text { Perusahaan manufaktur yang tidak menyediakan informasi } \\
\text { secara lengkap dan laporan keuangannya tidak dinyatakan dalam rupiah }\end{array}$ \\
5 & $\begin{array}{l}\text { Perusahaan yang tidak melakukan pergantian manajemen } \\
\text { yaitu direktur utama selama tahun amatan }\end{array}$ \\
& Jumlah Sampel Akhir \\
& $\begin{array}{l}\text { Tahun Pengamatan } \\
\text { Jumlah Pengamatan }\end{array}$
\end{tabular}

Statistik deskriptif bertujuan untuk memberikan gambaran atau deskripsi tentang variabel-variabel penelitian dari suatu data yang mencakup jumlah sampel, nilai rata-rata (mean), nilai minimum, nilai maksimum dan standar deviasi dari masing-masing variabel yang diteliti, yaitu pergantian manajemen, audit fee, reputasi auditor, dan auditor switching. 
Tabel 2.

Statistik Deskripstif Variabel-Variabel Penelitian

\begin{tabular}{cccccc}
\hline & N & Minimum & Maximum & Mean & Std. Deviation \\
\hline X1 & 90 &, 00 & 1,00 &, 2889 &, 45579 \\
X2 & 90 & 17,24 & 26,07 & 21,5371 & 1,80096 \\
X3 & 90 &, 00 & 1,00 &, 2222 &, 41807 \\
Y & 90 &, 00 & 1,00 &, 3000 &, 46082 \\
X1_X3 & 90 &, 00 & 1,00 &, 0556 &, 23034 \\
X2_X3 & 90 &, 00 & 26,07 & 5,2606 & 9,91584 \\
Valid N (listwise) & 90 & & & &
\end{tabular}

Sumber: Data diolah, 2018

Nilai minimum variabel pergantian manajemen sebesar 0 , nilai maksimum sebesar 1. Nilai minimum sesuai dengan tabulasi data dimana perusahaan yang terdapat pergantian manajemen 0 sebanyak 64 dan perusahaan yang memiliki nilai maksimum 1 sebanyak 26. Standar deviasi sebesar 0,45579 dan nilai rata-rata (mean) sebesar 0,2889. Nilai mean sebesar 0,2889 menunjukkan bahwa perusahaan yang melakukan pergantian manajemen lebih sedikit dibandingkan dengan perusahaan yang tidak melakukan pergantian manajemen.

Nilai minimum variabel audit fee sebesar 17,24, nilai maksimum sebesar 26,07. Nilai minimum sesuai dengan tabulasi data perusahaan Nusantara Inti Corpora Tbk tahun 2012 dan nilai maksimum sesuai dengan tabulasi data perusahaan Unilever Indonesia Tbk tahun 2016. Standar deviasi sebesar 1,80096 dan nilai rata-rata (mean) sebesar 21,5371. Nilai mean sebesar 21,5371 menunjukkan bahwa terdapat audit fee yang dibayarkan oleh perusahaan tinggi.

Nilai minimum variabel reputasi auditor sebesar 0 , nilai maksimum sebesar 1. Nilai minimum sesuai dengan tabulasi data dimana perusahaan yang memiliki reputasi auditor 0 sebanyak 70 dan perusahaan yang memiliki nilai maksimum 1 sebanyak 20. Standar deviasi sebesar 0,41807 dan nilai rata-rata 
Made Widi Wulandari dan I Dewa Gede Dharma Suputra. Pengaruh...

(mean) sebesar 0,2222. Nilai mean sebesar 0,2222 menunjukkan bahwa perusahaan yang menggunakan KAP yang berafiliasi dengan Big 4 lebih sedikit dibandingkan dengan perusahaan yang menggunakan KAP non Big 4.

Nilai minimum variabel auditor switching sebesar 0, nilai maksimum sebesar 1. Nilai minimum sesuai dengan tabulasi data dimana perusahaan yang terdapat auditor switching 0 sebanyak 63 dan perusahaan yang memiliki nilai maksimum 1 sebanyak 27. Standar deviasi sebesar 0,46082 dan nilai rata-rata (mean) sebesar 0,3000. Nilai mean sebesar 0,3000 menunjukkan bahwa perusahaan yang melakukan auditor switching lebih sedikit dibandingkan dengan perusahaan yang tidak melakukan auditor switching.

Selanjutnya dilakukan uji Kelayakan model regresi dinilai dengan menggunakan Hosmer dan Lemeshow's Goodness Of Fit Test. Pengujian dengan melihat Chi Square dengan nilai signifikansi sebesar 0,05. Hasil pengujian menunjukkan nilai Chi Square pada Hosmer dan Lemeshow's Goodness Of Fit Test adalah sebesar 12,819 dengan nilai signifikansi yaitu sebesar 0,118 . Hal ini menunjukkan nilai signifikansi 0,118 lebih besar dari 0,05 maka, model penelitian ini dapat diterima karena cocok dengan data observasinya.

Kemudian dilakukan uji Overall Model Fit dengan membandingkan nilai antara -2 Log Likelihood (-2LL) pada awal (Block Number $=0)$ dengan -2 Log Likelihood (-2LL) pada akhir (Block Number $=1)$. Apabila terdapat penurunan nilai Likelihood, menunjukkan model yang dihipotesiskan fit dengan data. Nilai 2LL awal (Block Number $=$ 0) adalah sebesar 109,956 dan setelah dimasukkan variabel-variabel independen, maka nilai -2LL akhir $($ Block Number $=1)$ 
mengalami penurunan sehingga menjadi 95,305. Penurunan -2LL menunjukkan model regresi yang lebih baik atau dengan kata lain model yang dihipotesiskan fit dengan data.

Besarnya nilai koefisien determinasi pada model regresi logistik ditunjukkan oleh nilai Nagelkerke $R$ Square. Nilai Nagelkerke $R$ Square yang tertera menunjukkan nilai variabilitas variabel dependen yang dapat dijelaskan oleh variabel independen, sedangkan sisanya dijelaskan oleh variabel-variabel lain diluar model penelitian. Hasil uji menunjukkan bahwa Nagelkerke $R$ Square sebesar 0,213 dan Cox \& Snell $R$ Square 0,150, yang menunjukkan bahwa kemampuan variabel independen dalam menjelaskan variabel dependen adalah sebesar 0,213 atau $21,3 \%$ dan terdapat $78,7 \%$ faktor lain di luar model yang menjelaskan variabel dependen.

Matriks klasifikasi menunjukkan kekuatan prediksi dari model regresi untuk memprediksi auditor switching yang dilakukan perusahaan.Berdasarkan tabel Classification Table, kemampuan memprediksi model regresi untuk kemungkinan perusahaan melakukan auditor switching sebesar 51,9\%. Sehingga dapat diketahui bahwa dengan menggunakan regresi tersebut, terdapat sebanyak 14 perusahaan atau 51,9\% yang diprediksi akan melakukan auditor switching dari total 27 perusahaan yang melakukan auditor switching. Sedangkan kemampuan memprediksi model regresi untuk kemungkinan perusahaan tidak melakukan auditor switching adalah sebesar 87,3\%. Sehingga dapat diketahui bahwa dengan menggunakan regresi tersebut, terdapat sebanyak 55 perusahaan atau 87,3\% yang diprediksi tidak melakukan auditor switching dari total 63 perusahaan yang tidak 
melakukan auditor switching. Nilai overall percentage sebesar $76,7 \%$ yang berarti ketepatan model penelitian ini adalah sebesar $76,7 \%$.

Tabel 3. Rekapitulasi Hasil Uji Regresi Logistik

\begin{tabular}{|c|c|c|c|c|c|c|c|}
\hline & & B & S.E. & Wald & Df & Sig. & $\operatorname{Exp}(B)$ \\
\hline \multirow[t]{6}{*}{ Step $1^{\mathrm{a}}$} & $\mathrm{X} 1$ & 2,018 &, 590 & 11,705 & 1 & ,001 & 7,524 \\
\hline & $\mathrm{X} 2$ & ,161 & ,210 &, 590 & 1 & ,442 & 1,175 \\
\hline & $\mathrm{X} 3$ & 10,181 & 10,686 & ,908 & 1 &, 341 & 26384,405 \\
\hline & X1_X3 & $-1,020$ & 1,282 & ,634 & 1 & ,426 & ,360 \\
\hline & $\mathrm{X} 2 \_\mathrm{X} 3$ &,- 445 & ,464 & 919 & 1 & ,338 & 641 \\
\hline & Constant & $-4,889$ & 4,459 & 1,202 & 1 & ,273 & ,008 \\
\hline
\end{tabular}

Berdasarkan hasil diatas, maka diperoleh model regresi sebagai berikut: $\operatorname{Ln} \frac{p(Y)}{1-P(Y)}=-4,889+2,018 \mathrm{X}_{1}+0,161 \mathrm{X}_{2}+10,181 \mathrm{X}_{3}-1,020 \mathrm{X}_{1} \cdot \mathrm{X}_{3}-0,445 \mathrm{X}_{2}$. $\mathrm{X}_{3}+\varepsilon$

Nilai konstanta sebesar $-4,889$ yang berarti apabila semua variabel independen bernilai konstan sama dengan nol, maka kecenderungan auditor switching sebesar -4,889. Koefisien regresi variabel pergantian manajemen sebesar 2,018 yang berarti setiap peningkatan pergantian manajemen, dengan asumsi variabel bebas lainnya dianggap konstan, maka kecenderungan auditor switching yang dilakukan perusahaan meningkat. Berdasarkan nilai koefisien regresi yang bernilai positif sebesar 2,018 serta nilai signifikansi diperoleh sebesar $0,001<0,05$, sehingga pergantian manajemen berpengaruh positif pada auditor switching. Koefisien regresi variabel audit fee sebesar 0,161 yang berarti setiap peningkatan pergantian manajemen, dengan asumsi variabel bebas lainnya 
dianggap konstan, maka kecenderungan auditor switching yang dilakukan perusahaan meningkat. Berdasarkan nilai koefisien regresi yang bernilai positif sebesar 0,161 serta nilai signifikansi diperoleh sebesar 0,442>0,05, sehingga audit fee tidak berpengaruh pada auditor switching.Koefisien regresi variabel reputasi auditor sebesar 10,181 yang berarti, apabila reputasi auditor naik, dengan asumsi variabel bebas lainnya dianggap konstan, maka kecenderungan auditor switching yang dilakukan perusahaan meningkat. Koefisien regresi variabel interaksi antara variabel pergantian manajemen dengan variabel reputasi auditor menunjukkan nilai koefisien bernilai negatif sebesar -1,020. Berdasarkan nilai koefisien regresi yang bernilai negatif sebesar $-1,020$ serta nilai signifikansi diperoleh sebesar 0,426>0,05. Hasil tersebut menunjukkan bahwa reputasi auditor tidak dapat memoderasi pengaruh pergantian manajemen pada auditor switching. Koefisien regresi variabel interaksi antara variabel audit fee dengan variabel reputasi auditor menunjukkan nilai koefisien bernilai negatif sebesar 0,445 serta nilai signifikansi diperoleh sebesar $0,338>0,05$. Hasil tersebut menunjukkan bahwa reputasi auditor tidak dapat memoderasi pengaruh audit fee pada auditor switching.

Hipotesis pertama menyatakan bahwa variabel pergantian manajemen berpengaruh positif pada auditor switching. Berdasarkan hasil analisis pengaruh pergantian manajemen pada auditor switching diperoleh nilai signifikansi sebesar dengan nilai koefisien regresi positif sebesar 2,018. Nilai signifikansi 0,001<0,05 mengindikasikan bahwa $\mathrm{H}_{0}$ ditolak dan $\mathrm{H}_{1}$ diterima. Hasil ini mempunyai arti bahwa variabel pergantian manajemen berpengaruh positif pada auditor 
Made Widi Wulandari dan I Dewa Gede Dharma Suputra. Pengaruh...

switching. Hasil penelitian ini sejalan dengan teori keagenan yang menyebutkan adanya perbedaan tujuan dan kepentingan antara principal dan agen memicu timbulnya agency problem. Timbulnya konflik ini dikarenakan pihak manajemen yang berperan sebagai agen memiliki dan mengejar kepentingan pribadinya dalam menjalankan perusahaan sehingga kepentingan atau keinginan dari pemegang saham sebagai pemilik perusahaan tidak dapat dicapai. Hal ini membuat principal kehilangan kepercayaan kepada agen dan memilih mengganti manajemen perusahaan. Penelitian ini mendukung hasil penelitian yang dilakukan (Cooke, 2005), (Astika \& Pratini, 2013), dan (Pradhana, 2015), menyatakan bahwa pergantian manajemen berpengaruh positif pada auditor switching. Pergantian manajemen suatu perusahaan disebabkan karena adanya keputusan rapat umum pemegang saham (RUPS) atau pihak manajemen berhenti karena kemauan sendiri, sehingga pemegang saham harus mengontrak atau mengganti manajemen baru yaitu direktur utama. Dengan adanya manajemen yang baru mengakibatkan perubahan pada kebijakan di dalam perusahaan seperti dalam bidang akuntansi, keuangan dan juga pemilihan akuntan publik atau kantor akuntan publik (KAP). Pihak manajemen tentunya memerlukan kualitas audit yang lebih baik sehingga ada kemungkinan jika perusahaan cenderung mengganti auditornya.

Hipotesis kedua menyatakan bahwa variabel audit fee berpengaruh positif pada auditor switching. Berdasarkan hasil analisis pengaruh audit fee pada auditor switching diperoleh nilai signifikansi sebesar 0,442 dengan nilai koefisien regresi positif sebesar 0,161 . Nilai signifikansi $0,442>0,05$ mengindikasikan bahwa $\mathrm{H}_{0}$ diterima dan $\mathrm{H}_{2}$ ditolak. Hasil ini mempunyai arti bahwa variabel audit 
fee tidak berpengaruh pada auditor switching. Hasil penelitian ini mendukung penelitian sebelumnya yang dilakukan oleh (Chadegani et al., 2011), (Arinta \& Adiwibowo, 2013) menyatakan bahwa audit fee tidak memiliki pengaruh yang signifikan pada auditor switching. Namun bertentangan dengan hasil penelitian (Ramantha, 2014), (Pradhana, 2015) yang menyatakan bahwa audit fee berpengaruh positif pada auditor switching. Penelitian yang dilakukan (Lestari, 2012) menyatakan bahwa audit fee yang tinggi maupun rendah tidak mempengaruhi perusahaan untuk melakukan auditor switching. Fee audit dapat didefinisikan sebagai jumlah biaya yang dibebankan oleh auditor untuk proses audit kepada perusahaan (auditee). Fee audit biasanya ditentukan sebelum memulai proses audit. Besarnya fee yang diberikan tidak berpengaruh terhadap pergantian auditor, asalkan sejalan dan memenuhi kualifikasi yang dibutuhkan perusahaan. Pergantian auditor tersebut terjadi karena perusahaan menilai kualitas yang dimiliki auditor tidak sesuai dengan opini yang diharapkan perusahaan.

Hipotesis ketiga menyatakan bahwa reputasi auditor memperlemah pengaruh pergantian manajemen pada auditor switching. Hasil pengujian menunjukkan bahwa koefisien regresi negatif sebesar $-1,020$ dengan nilai signifikansi sebesar $0,426>0,05$, mengindikasikan bahwa $\mathrm{H}_{0}$ diterima dan $\mathrm{H}_{3}$ ditolak. Hasil tersebut menunjukkan dengan adanya reputasi auditor tidak dapat memoderasi pengaruh pergantian manajemen pada auditor switching. Hasil penelitian ini tidak sejalan dengan teori kontingensi, yang menyatakan bahwa perbedaan desakan lingkungan perusahaan menjadi acuan pihak manajemen dalam memilih sistem akuntansi yang akan diberlakukan di perusahaan tersebut. 
Made Widi Wulandari dan I Dewa Gede Dharma Suputra. Pengaruh...

Akibat dari desakan lingkungan perusahaan yaitu para pengguna laporan keuangan yang menganggap bahwa semakin bertumbuhnya sebuah perusahaan maka akan menggunakan auditor yang lebih baik dalam konteks reputasi. Perusahaan cenderung menggunakan kantor akuntan publik yang berafiliasi dengan Big Four, karena kantor akuntan publik yang berafiliasi dengan Big Four memiliki indenpendensi dan kompetensi yang lebih baik dibandingkan kantor akuntan publik Non Big Four. Penelitian yang dilakukan oleh (Yuliani et al., 2016) menyatakan bahwa reputasi auditor tidak mampu memoderasi pergantian manajemen terhadap pergantian auditor, dikarenakan adanya pergantian manajemen yang dilakukan oleh perusahaan akan menimbulkan kebijakankebijakan yang baru termasuk dalam pemilihan KAP maupun auditor. Apapun reputasi auditornya selama dapat memberikan opini yang diharapkan manajemen, baik lama maupun baru maka auditor tersebut tidak akan diganti.

Hipotesis keempat menyatakan bahwa reputasi auditor memperlemah pengaruh audit fee pada auditor switching. Hasil pengujian menunjukkan bahwa koefisien regresi negatif sebesar $-0,445$ dengan nilai signifikansi sebesar $0,338>$ 0,05 mengindikasikan bahwa $\mathrm{H}_{0}$ diterima dan $\mathrm{H}_{4}$ ditolak. Hasil tersebut menunjukkan dengan adanya reputasi auditor tidak dapat memoderasi pengaruh audit fee pada auditor switching. Dalam teori kontingensi, sifat dasar seorang manajemen adalah situsional. Situsional yang dimaksud yaitu menghadapi konseksuensi dalam pemilihan teknik - teknik manajemen bergantung pada situasi lingkungan. Manajemen harus mengadopsi pendekatan dan strategi sesuai dengan permintaan setiap situasi yang dihadapi. Strategi manajemen untuk 
meningkatkan citra perusahaan dimata stakeholders yaitu salah satunya dengan menggunakan kantor akuntan publik yang berafiliasi Big 4. Penelitian yang dilakukan (Amalia, 2015) mendukung bahwa variabel reputasi auditor tidak mampu memoderasi hubungan antara audit fee pada auditor switching. Reputasi auditor merupakan nama besar yang dimiliki auditor atas prestasi dan kepercayaan publik yang disandang auditor tersebut. Reputasi auditor sangat menentukan kredibilitas (kualitas, kapabilitas, atau kekuatan untuk menimbulkan kepercayaan) suatu laporan keuangan. Perusahaan cenderung memakai jasa kantor akuntan publik yang sudah memiliki reputasi tinggi, hal tersebut sebagai wujud pencitraan dan menambah kepercayaan diri sebuah perusahaan untuk menarik calon investornya.

\section{SIMPULAN}

Kesimpulan dari penelitian ini yaitu: 1) Pergantian manajemen berpengaruh positif pada auditor switching. Hal ini berarti bahwa perusahaan yang mengalami pergantian manajemen mengakibatkan perubahan pada kebijakan di dalam perusahaan seperti dalam bidang akuntansi, keuangan dan juga pemilihan akuntan publik atau kantor akuntan publik (KAP) dibandingkan dengan perusahaan yang tidak mengalami pergantian manajemen; 2) Audit fee tidak berpengaruh pada auditor switching. Hal ini berarti bahwa audit fee yang tinggi maupun rendah tidak mempengaruhi perusahaan untuk melakukan auditor switching dan KAP tersebut dapat sejalan dan memenuhi kualifikasi yang dibutuhkan perusahaan; 3) Reputasi auditor tidak mampu memoderasi pengaruh pergantian manajemen pada auditor switching. Hal ini berarti bahwa reputasi apapun yang dimiliki auditor 
Made Widi Wulandari dan I Dewa Gede Dharma Suputra. Pengaruh...

selama dapat memberikan opini yang diharapkan manajemen baik lama maupun baru, maka auditor tersebut tidak akan diganti; dan 4) Reputasi auditor tidak mampu memoderasi pengaruh audit fee pada auditor switching. Hal ini berarti bahwa manajemen menganggap KAP besar maupun kecil sama-sama mempunyai reputasi yang baik sehingga tidak perlu untuk melakukan auditor switching. Perbedaan audit fee yang dibayarkan kemungkinan telah sesuai dengan tingkat kompleksitas pekerjaan yang dilakukan oleh KAP dalam melakukan audit atas laporan keuangan. Persetujuan audit fee dalam hal ini sudah dianggap wajar, serta pembayaran audit fee kemungkinan tidak membebani perusahaan.

Adapun beberapa hal yang dapat disarankan sesuai dengan hasil pembahasan hingga kesimpulan yang disajikan pada penelitian ini meliputi: 1) Peneliti berharap, baik kantor akuntan publik yang berafiliasi dengan Big Four maupun yang tidak berafiliasi dengan Big Four mampu mempertahankan independensi dan meningkatkan kualitas audit yang dihasilkan, sehingga mampu memberikan jaminan akan kewajaran laporan keuangan suatu entitas. Kedepannya agar tidak hanya kantor akuntan publik yang berafiliasi dengan Big Four yang mendapat kepercayaan masyarakat luas, tetapi juga KAP Non Big Four. 2) Diharapkan, perusahaan mampu mengindikasikan penyebab terjadinya auditor switching secara voluntary. Sehingga dalam kondisi terjadinya pergantian manajemen perusahaan, perusahaan tidak langsung melakukan auditor switching. 3) Penelitian ini menunjukkan nilai R Square sebesar 0,282 yang artinya variabel bebas yang digunakan dalam penelitian ini mempengaruhi variabel terikat sebesar $28,2 \%$ dan $71,8 \%$ dipengaruhi oleh variabel lain. Penelitian selanjutnya, 
diharapkan dapat menyempurnakan penelitian ini dengan menambah variabel lain yang dapat mempengaruhi auditor switching yaitu menambahkan variabel rasiorasio keuangan dan non keuangan seperti rasio rentabilitas, profitabilitas, solvabilitas serta opini audit, kualitas audit, ukuran perusahaan, dan kesulitan keuangan.

\section{REFERENSI}

Ali, K. H. (2015). Determinants of Auditor Switching in Bahraini'S Listed Companies - an Empirical Study. European Journal of Accounting, Auditing and Finance Research, 3(11), 73-99. https://doi.org/10.1017/CBO9781107415324.004

Amalia, R. F. (2015). Pengaruh Opini Audit, Pergantian Manajemen, Audit Fee , Terhadap Auditor Switching Secara Voluntary Dengan Reputasi Auditor Sebagai Variabel Moderating, 5(3), 161-178.

Astrini, N. R., \& Muid, D. (2013). Analisis Faktor-Faktor Yang Mempengaruhi Perusahaan Melakukan Auditor Switching Secara Voluntary, 2, 1-11.

Chadegani, A. A., Mohamed, Z. M., \& Jari, A. (2011). The Determinant Factors of Auditor Switch among Companies Listed on Tehran Stock Exchange. International Research Journal of Finance and Economics, 80(80), 158-168.

Damayanti, S., \& Sudarma, M. (2008). Faktor-Faktor yang Mempengaruhi Perusahaan Berpindah Kantor Akuntan Publik. Simposium Nasional Akuntansi XI, 1-23.

El-Gammal, W. (2012). Determinants of Audit Fees: Evidence from Lebanon. International Business Research, 5(11). https://doi.org/10.5539/ibr.v5n11p136

Francis, J. R., \& Yu, M. (2009). The effect of Big Four office size on audit quality. The Accounting Review, 84(May), 521-1552. https://doi.org/10.2308/accr.2009.84.5.1521

Lawrence, P. R., \& Lorsch, J. W. (1967). Organization and Enviornment. Boston, MA:Harvard Business School Press.

Nagy, A. L. (2005). Mandatory audit firm turnover, financial reporting quality, and client bargaining power: The case of arthur andersen. Accounting Horizons, 19(2), 51-68. https://doi.org/10.2308/acch.2005.19.2.51 
Pawitri, N. M. P., \& Yadnyana, K. (2015). Pengaruh Audit Delay , Opini Audit, Reputasi Auditor Dan Pergantian Manajemen Pada Voluntary Auditor Switching. E-Jurnal Akuntansi Universitas Udayana, 1(10), 214-228.

Pradhana, M. A. B. (2015). Pengaruh Audit Fee, Going Concern, Financial Distress, Ukuran Perusahaan, Pergantian Manajemen Pada Pergantian Auditor. Jurnal Akuntansi Universitas Udayana, 11.3, 713-729. https://doi.org/10.1017/CBO9781107415324.004

Putra, I. G. B. B. P., \& Suryanawa, I. K. (2016). Pengaruh Opini Audit Dan Reputasi Kap Pada Auditor Switching Dengan Financial Distress Sebagai Variabel Moderasi. E-Jurnal Akuntansi Universitas Udayana, 14(2), 11201149.

Ramantha, N. L. P. P. N. A. dan I. W. (2014). Pengaruh Audit Fee, Opini Going Concern, Financial Distress Dan Ukuran Perusahaan Pada Pergantian Auditor. E-Jurnal Akuntansi Universitas Udayana, 7(3), 663-676.

Saputra, G. (2015). Pengaruh Opini Going Concern dan Pergantian Manajemen Terhadap Auditor Switching, Reputasi Auditor Sebagai Variabel Moderasi. Jurnal Jurusan Akuntansi Fakultas Ekonomi Universitas Riau, 4(1), 32563268 .

Sari, 2016. (2016). Reputasi Auditor Sebagai Pemoderasi Pengaruh Audit Fee pada Auditor Switching. E-Jurnal Akuntansi Universitas Udayana, 16, 527556.

Satriantini, P., Sinarwati, N. K., \& Sri, L. M. (2014). Pengaruh Pergantian Manajemen, Opini Audit, dan Ukuran KAP Terhadap Pergantian KAP Pada Perusahaan Real Estate dan Properti yang Terdaftar di BEI Periode 2009-2013. Jurnal Akuntansi SI, 2(1).

Sidhi, B. A. D. M., \& Wirakusuma, M. G. (2015). Pengaruh Ukuran Perusahaan, Tingkat Penjualan Perusahaan, dan Reputasi KAP pada Pergantian KAP. EJurnal Akuntansi Universitas Udayana, 13(3), 723-736.

Sinarwati, N. K. (2010). Mengapa Perusahaan Manufaktur yang Terdaftar di BEI Melakukan Pergantian Kantor Akuntan Publik? PhD Proposal, 1, 1-20. https://doi.org/10.1017/CBO9781107415324.004

Siregar, S. V., Amarullah, F., Wibowo, A., \& Anggraita, V. (2012). Audit tenure, auditor rotation, and audit quality: The case of Indonesia. Asian Journal of Business and Accounting, 5(1), 55-74.

Susanto, O. P. (2015). Faktor-faktor yang mempengaruhi perusahaan melakukan auditor switching. Jurnal Akuntansi Universitas Udayana. 
Suyono, E., Yi, F., \& Riswan. (2013). Determinant Factors Affecting The Auditor Switching: An Indonesian Case. Global Review of Accounting and Finance, 4(2), 103-116.

Wayan, N., Juliantari, A., \& Rasmini, N. K. (2013). Auditor Switching Dan Faktor-Faktor Yang Mempengaruhinya. Jurnal Akuntansi Universitas Udayana, 33, 2302-8556.

Wibowo, A., \& Rossieta, H. (2006). Faktor-Faktor Determinasi Kualitas Audit Suatu Studi Dengan Pendekatan Earnings Surprise Bencmark. Jurnal Akuntansi, 2(2006), 34.

Widyanti, A.A. S Istri, A., \& Badera, I. D. N. (2016). Reputasi Auditor Sebagai Pemoderasi Pengaruh Financial Distress Pada Auditor Switching. Jurnal Akuntansi Universitas Udayana, 16.3, 1800-1828.

Wijaya, E. (2015). Pengaruh Audit Fee, Opini Going Concern, Financial Distress, Ukuran Perusahaan, dan Ukuran KAP pada Pergantian Auditor Perusahaan Manufaktur yang Terdaftar di Bursa Efek Indonesia Periode 2008-2013. Jurnal Akuntansi Universitas Udayana, 53(9), 940-966. https://doi.org/10.1017/CBO9781107415324.004

Yuliani, R., Sukarmanto, E., \& Purnamasari, P. (2016). Pengaruh Pergantian Manajemen dan Audit Delay terhadap Pergantian KAP dengan Reputasi KAP sebagai Variabel Moderasi ( Studi Empiris Pada Perusahaan yang Masuk Dalam Indeks LQ45 di Bursa Efek Indonesia Tahun 2013-2016 ), 262-268. 